\title{
The Effect of Collocational Success on Essay Grading: A Case of Algerian EFL Learners
}

Received: 06/10/2018 ; Accepted: 12/06/2019

\begin{abstract}
Collocations are an inherent and indispensable part of the language continuum. This work investigates the mastery of Verb+Noun lexical collocations by Algerian EFL learners at the University of Mentouri Brothers, Constantine 1. It is hypothesised that Algerian EFL learners have a low level of mastery in the usage and comprehension of Verb+Noun collocations. It is also hypothesised that the essays of Algerian EFL learners lack the use of appropriate Verb+Noun collocations, a factor that influences the grades they receive. An online corpus (BNC) and two other online websites (Collocation Checker \& O.O.C.D) were used as tools to measure learners' collocational competence. Examined collocations were extracted from the learners' examination essays. The analysis was done manually through identification and corpus usage. The findings reveal that the Verb+Noun collocational errors that were spotted were not taken in consideration during the correction, even though they are an indispensable part that guarantees the use of correct language. The findings also confirm the aforementioned hypotheses, in addition to the fact that teachers are either unaware of the impact of collocations on the writing quality, or did not take them into account, because they did not teach them. This could be noted by the fact that even the essays that received the highest grades contain many collocational errors.
\end{abstract}

Keywords: Verb+Noun Collocations; Highest Grades; Essays.

\section{Mohamed Akram} ARABET *

Faculty of Letters and Languages

Department of Foreign

Languages

University of Mentouri

Constantine I

(Algeria)

\section{Résumé}

Les collocations sont des sections inhérentes et indispensables de la langue. Cette recherche étudie la maitrise des collocations lexicales du type Verbe+Nom, par les étudiants Algériens à l'université des Frères Mentouri, Constantine 1. La première hypothèse propose que les étudiants Algériens d'Anglais possèdent un niveau de maîtrise bas des collocations lexicales du type Verbe+Nom. La deuxième hypothèse suggère que les essais des étudiants Algériens d'Anglais manquent d'usage approprié des collocations lexicales du type Verbe+Nom; un facteur qui influence les notes qu'ils reçoivent. Un corpus en ligne (B.N.C), et deux autres sites en ligne (collocation checker \& O.O.C.D) ont été utilisés comme outils pour mesurer la compétence des collocations par les apprenants. Les collocations examinées ont été extraites des essais des examens pris par les étudiants. L'analyse a été faite manuellement par identification et usage du corpus. Les résultats suggèrent que les collocations du type Verbe+Nom n'ont pas été prises en considération pendant la correction, malgré qu'elles sont indispensables pour garantir un usage correct de la langue. Ils confirment aussi les hypothèses susmentionnées, en plus de ça le fait que les enseignants sont, soit ignorants de l'impact des collocations sur la qualité d'écriture, ou ils ne les ont pas pris en compte, parce qu'ils ne leur ont pas été enseignées. Cela pourrait être noté par le fait que les essais qui ont eu les notes les plus élevées contiennent beaucoup de fautes en collocations lexicales.

Mots clés: Collocations du Type Verbe+Nom; les Notes les plus

Elevées; les Essais.

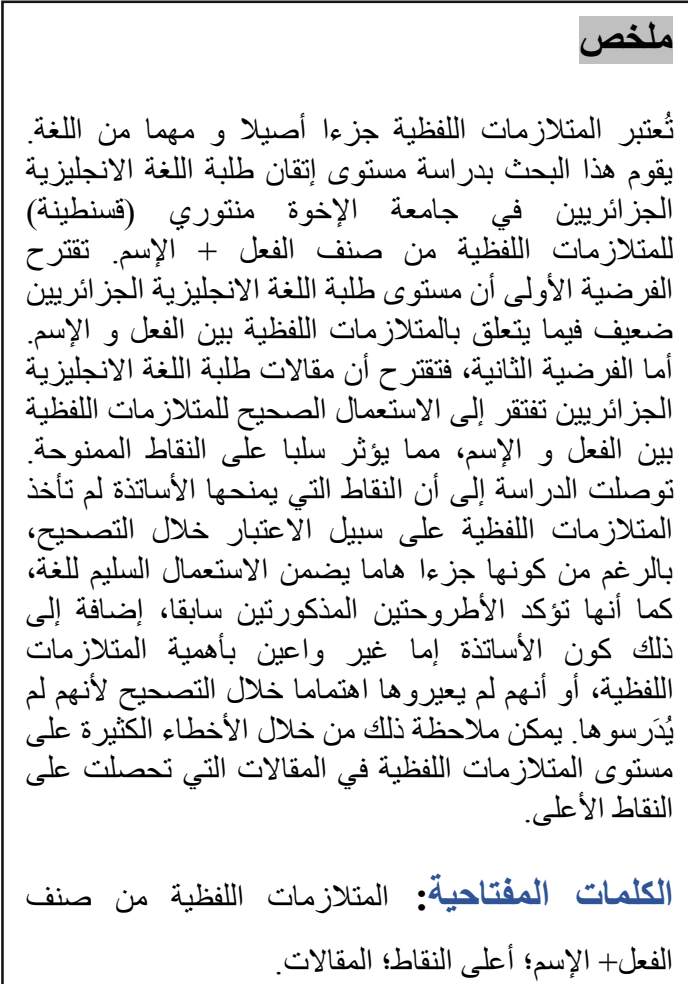

* Corresponding author, e-mail: arabetdoctorat@gmail.com 


\section{Introduction}

Inadequate research has been carried out in the area of collocation. Although some researchers have shown interest in collocations, extensive research still needs to be undertaken to highlight its practical importance in improving EFL learners' overall linguistic competence. The topic of collocation raises many questions concerning the measurement of learners' collocational competence, the best methods to teach collocations, or the types of collocations to focus on. In order to be able to answer these questions, it is necessary to, first, identify the difficulties in mastering collocations. This study focuses on Verb + Noun lexical collocations as the mostly used type of collocations. Hatch and Brown (1995) stated that learners acquire collocations in chunks rather than as separate words. The same thing goes to L1 users. In other words, L2 learners learn collocations like infants do. The main problem with some studies about collocation - as a concept - is that the definition is vague; no clear and specific definition is given, which makes experimentation difficult. Firth (1957) defines collocation as the best company a word keeps. Such definition might seem ubiquitous of the notion; however, with careful examination, one would respond by saying that not all words that co-occur are collocations. The present study attempts to shed some light on Algerian EFL learners' knowledge of collocation in essay writing. It investigates the correlation between collocational failure and the overall grading in the Written Expression module.

\section{Literature Review}

An essential introduction to the study of language is made by tackling the topic of word knowledge. A distinction is drawn between the three types of word knowledge: knowledge of form, knowledge of meaning, and knowledge of use. These three types make up for the whole study of language. In light of this concept, the notion of collocation can be defined and explained. By understanding what collocations are, one will be able to identify them on the language continuum and distinguish them from free combinations and idioms.

\subsection{Definition of Collocation}

Collocations have been recognised to distinguish a native speaker from a foreign language learner. Usually, one way a non-native speaker may offer help is by saying "Can I help you?" Meanwhile a native speaker would say "Can I give you a hand?" (Salkauskiene, 2002, as cited in Farrokh, 2012, p. 56). Although a non-native speaker might succeed syntactically, he/she may not sound a native-like in terms of which words combine with which. English, similar to many languages, has its own share of re-occurring word combinations. These word combinations arbitrarily co-occur. A native speaker says 'ultimate goal' and not 'last goal'; one 'pays a visit', but does not 
'make a visit' (Farrokh, 2012, p. 56). Prodromou (2004, as cited in Farrokh, 2012, p. 56) says:

knowing the meaning of a word not only requires knowing its dictionary definition; one must also know the type of words with which it is often associated. Collocations, either fixed or more flexible, are the result of many years of habitual use by fluent speakers of the English.

Ganji (2012, p. 125) also discussed the notion of collocation. According to him, it is "a string of words that must or should be learned, or is best or most conveniently learnt as an integral whole or independent entity, rather than by the process of piecing together their component parts". Firth (1957) followed, later, and was recognised as the one who introduced this concept to the world.

During the last decades, research in linguistics has given much importance to collocation. Scholars, teachers, and corpus designers have become aware of its importance during the language learning process. They mentioned that the increase in linguistic competence is primary in the enhancement of learners' communicative competence, and the approximation to native-like fluency (Darvishi, 2011, p. 52). On the same note, teachers' ability to identify collocational errors to EFL leaners can significantly increase their awareness of the subject. Therefore, studying miscollocations is equally important to studying correct ones, for it helps instructors focus on the difficult ones (Darvishi, 2011, pp. 52-53).

Focus on collocation by many scholars led to a variety of definitions. For Firth (1957, p. 179) "you shall know a word by the company it keeps.” According to Lewis (1997, p.44) "collocations are those combinations of words which occur naturally with greater than random frequency. Collocations co-occur, but not all words which cooccur, are collocations." This states clearly that collocations have their specific characteristics which distinguish them from other word combinations like free combinations and idioms. Hardi (2008, as cited in Lewis 1997, p.44) defines collocation as "words that occur together in a text. This co-occurrence, he believes, is frequent enough to make a pair of words as a collocational phrase". Those words denote the characteristic of frequency which is primary to identifying collocations. However, frequency hits that qualify a certain word combination to move from free combination to collocation differ according to scholars and corpora. Some scholars set the bar to 40 hits per 100 million words; others suggest the hits should reach 50 hits per 100 million words.

\subsection{Collocational Competence}

As much as grammatical competence is important to reach native-like proficiency, collocational competence helps significantly make a foreign language learner a pseudonative speaker. There are many advantages that collocational competence offers. 
According to Henriksen (2013, p. 33), collocational competence helps to use correct idiomatic expressions in a native-like way, to cognitively analyse language, to be more reliable and present in the conversation, to understand polysemous words, and to comprehend word connotation. In other words, appropriate understanding of collocations allows the reader or listener to achieve communicative competence.

\subsection{Types of Collocations}

The various perspectives the notion of collocation was viewed from led to a different categorisation. For Lewis (1997, p. 44), collocations were classified into strong, weak, frequent, and infrequent. The categorisation adopted in this research is developed by Bahns (1993). According to him (p. 57), collocations can be classified into two main categories: grammatical collocations and lexical collocations.

Grammatical collocations contain prepositions, sometimes occurring with verbs, nouns, or adjectives, e.g. (reach down, put forth), (by car, on foot), or (interested in, happy with) (McKeown \& Radev, 1995, p. 05). Bahns (1993, p. 57) notes that they "(usually) consist of a noun, an adjective or a verb, plus a preposition or a grammatical structure such as an infinitive or clause."

On the other hand, Benson (1985, p. 62) explains that "lexical collocations contain no subordinate element; they consist of two lexical components." This means that there are no grammatical components within the word combination, only lexical ones (content words). According to Gabrielatos (1994, p. 02):

there are three factors determining the categorising of a lexical collocation: the degree of probability that the items will cooccur, the degree of fixity of the combination (i.e. grammatical restrictions), and the degree to which the meaning of the combination can be derived from its constituent parts.

Therefore, lexical collocations are "restricted lexically" (McKeown \& Radev, 1995, pp. 05-06)

There are six types of lexical collocations:

1. Verb + noun: pay a visit.

2. Adjective + noun: heavy rain.

3. Noun + verb: the cat cuddles.

4. Adjective + adjective: closely related.

5. Verb + adverb: announce happily.

6. Adverb + adjective: totally bewitched (Bahns, 1993). 


\subsection{Collocations as an Indispensable Factor for Understanding Speech/Writing}

Formulaic language is an inherent part of the linguistic system; collocations form part of the former. It is embedded in the syntax, as well as the semantics and pragmatics. Hence, it cannot be discredited from the process of language learning and evaluation. Thinking that one can produce correct language without choosing the appropriate word combinations is a limited understanding of the mechanism of the language continuum. In this respect, Altenberg claims that up to $80 \%$ of adult native speaker language may be formulaic (as cited in Wray 1999, p. 214). In a later study, Erman and Warren (as cited in Wood, 2009, p. 42) state that $58.6 \%$ of the corpus investigated in their study was made up of the various types of formulaic sequences. These numbers are considered as a strong evidence of the dominance of formulaic language in language usage. They also prove that they are the most important part of it, because, were they not that paramount, no idioms or collocations would exist in language. Thus, one would not expect to hear 'good morning', 'good evening', and similar expressions on a daily basis; one would expect novel expressions every day, and society would never be able to agree on communicative patterns that govern their use of language. All this would certainly result in no 'langue.'

\section{The Study}

The present work investigates the use of Verb+Noun lexical collocations in the essays of Algerian second year undergraduate EFL learners at the University of Mentouri Brothers, Constantine 1. It is to discuss the following questions:

1.To what extent do second year EFL undergraduate students at the University of Mentouri Brothers, Constantine 1 master the use of Verb+Noun collocational language while writing essays?

2. To what extent do the Verb+Noun collocational errors influence the grades received by second year Algerian EFL undergraduate students at Université des Frères Mentouri, Constantine 1?

The hypotheses laid out for this study are as follows:

1.Algerian EFL second year undergraduate students at the University of Mentouri Brothers, Constantine 1, have a low level of mastery in the usage of $\mathrm{V}+\mathrm{N}$ collocations.

2. The grades Algerian EFL second year undergraduate students at the University of Mentouri Brothers, Constantine 1 have received are influenced by the lack of use of the $\mathrm{V}+\mathrm{N}$ appropriate collocations.

\subsection{Data Gathering Tools}


The study used three research tools: Collocation checker, Oxford Online Collocation Dictionary (O.O.C.D), and the British National Corpus (BNC).

Collocation checker is an online software that permits the researcher to identify correct and erroneous collocations. It shares the same database as that of BNC. All word combinations retrieved from students' essays were analysed via this software.

The second tool is O.O.C.D, an online software, too. It provides all the possible collocational hits for the searched word, in addition to examples retrieved from the BNC. Its main function-in this study - is to distinguish collocations from free combinations.

The British National Corpus is the third tool. It is an online corpus that comprises 100 million words. BNC contains authentic data and is considered as a reliable source for examining collocations. A high-frequency hit in BNC is proof of a well-combined word combination. Examples are provided in Table 01. The basic threshold in this study is 40 hits for a single word combination. All word combinations that did not score 40 hits were considered as free combinations, instead.

\subsection{Research Method}

The present section describes the research method applied in the study. It contains the frequent examples, the main criteria for selecting collocations, and the method of application of the research tools.

\begin{tabular}{|c|c|c|c|}
\hline Pattern & $\begin{array}{c}\text { Correct } \\
\text { Collocation }\end{array}$ & $\begin{array}{c}\text { Erroneous } \\
\text { Collocation }\end{array}$ & $\begin{array}{c}\text { Suggestion for } \\
\text { Improvement }\end{array}$ \\
\hline $\mathbf{V + N}$ & $\begin{array}{c}\text { attend classes } \\
\text { do homework } \\
\text { answer a question }\end{array}$ & $\begin{array}{c}\text { stare star } \\
\text { promote appetite } \\
\text { do preparation } \\
\text { pay time }\end{array}$ & $\begin{array}{c}\text { watch star } \\
\text { increase appetite } \\
\text { make preparation } \\
\text { spend time }\end{array}$ \\
\hline
\end{tabular}

Table 01: Typical V+N Collocation Type Found in This Study

The study was based on three criteria to identify acceptable collocations and erroneous ones. Table 02 illustrates these criteria.

\begin{tabular}{|c|l|}
\hline Criterion 01 & $\begin{array}{l}\text { The sense of the verb is so specific that it can only combine } \\
\text { with a small set of nouns. }\end{array}$ \\
\hline Criterion 02 & $\begin{array}{l}\text { The verb in this sense cannot be replaced by their syntactically } \\
\text { and semantically possible choices. }\end{array}$ \\
\hline Criterion 03 & $\begin{array}{l}\text { Word combinations which have high frequency hits in the } \\
\text { British National Corpus are considered as well-formed } \\
\text { collocations (40 hits). }\end{array}$ \\
\hline
\end{tabular}

\section{Table 02: Criteria for Choosing Collocation in This Study}

The initial two criteria are flexible; however, the third one is fixed. In other words, the verb is considered to be 'restricted' if one or both of the restrictedness and substitutability criteria were met. Nonetheless, the combination has to score, at least, 40 hits. 
A primary task was to identify erroneous collocations. The three research tools were used in the aforementioned order.

A collocation checker was used to spot wrong collocations. After a word combination is inputted, collocation checker indicates whether the combination is correct or erroneous. However, that does not entail that all acceptable word combinations -according to collocation checker-are collocations. After identifying wrong collocations, the second task was to distinguish free combinations from collocations. O.O.C.D was used to determine whether the verb + noun being investigated collocate or not.

BNC came as a final step to ensure that word combinations labelled as 'collocations' by O.O.C.D thoroughly fulfil the third criterion, high frequency of cooccurrence. If a combination were labelled as a 'collocation' by O.O.C.D, but did not score, at least, 40 hits in BNC, it would be classified as a free combination.

The efficacy of using all of the three online tools is that they share the same database, which ensures congruence in results.

\subsection{Population and Sampling}

The sample (66 essays) chosen for the study consists of second year EFL students at the University of Mentouri Brothers, Constantine 1. These 66 students have been studying English for nine years. They study Written Expression for three sessions per week, the equivalent of 4.5 hours for the last 2 years. The samples analysed in the study are students' essays that were written during the second semester's examinations. The reason behind the selection of examinations' essays is to ensure seriousness in production since these essays were rated by Written Expression teachers. The topics were mainly social ones: gifts received in the past, students' dream house, and the consequences of moving out of one's native town. Such topics are common to students, and they, presumably, possess the appropriate vocabulary and ideas to elaborate on them. 66 randomly-selected essays were analysed, which is fifth of the total number. It is worthy to mention that the examples reported from students' essays were copied with all the mistakes.

\subsection{Results and Discussion}

The study resulted in 616 word combinations (free combinations, collocations, and idioms). In Table 03, proportionate numbers of each category are represented.

\begin{tabular}{|c|c|c|c|}
\hline Free Combinations & Collocations & Idioms & Total \\
\hline 379 & 237 & 0 & 616 \\
\hline $61.53 \%$ & $38.47 \%$ & $00 \%$ & $100 \%$ \\
\hline
\end{tabular}

Table 03: Total Number of Word Combinations in Students' Compositions 
It is predictable that learners use free combinations more than collocations, and that idioms will be of a lesser use. The reason is that collocations and idioms are context-bound and of arbitrary use. What is noticeable is that in the 66 essays written by the students, no idiom was identified.

237 collocations were found in students' compositions. Only $38.82 \%$ of them were correct. Table 04 illustrates the findings.

\begin{tabular}{|c|c|c|}
\hline \multirow{2}{*}{ Composition } & Acceptable Collocations & Unacceptable Collocations \\
\cline { 2 - 3 } & 92 & 145 \\
\cline { 2 - 3 } & $38.82 \%$ & $61.18 \%$ \\
\hline
\end{tabular}

Table 04: Frequency of Acceptable/Unacceptable Collocations in Students'

\section{Compositions}

The high percentage of erroneous collocations shows clearly that the sample students lack collocational competence. Although students were given partial freedom to choose topics to write about, they were unsuccessful in using the appropriate $\mathrm{V}+\mathrm{N}$ combinations - based on the context of writing. These results open speculation on students' ability to use the most common type of lexical collocations $(\mathrm{V}+\mathrm{N})$ if writing topics were more difficult and more science-based.

The following section focuses on the essays with the highest grades. It attempts to examine the influence of $\mathrm{V}+\mathrm{N}$ collocational errors on the grades. It also investigates Written Expression teachers' awareness of collocations during the correction. In this sense, it considers 06 copies that were awarded with the highest grades. It is important to state that the examples were copied from learners' essays, including their spelling mistakes.

\section{Copies with the Highest Grades}

\section{Copy Number 01}

\begin{tabular}{|c|c|c|}
\hline $\begin{array}{c}\text { Number of Free } \\
\text { Combinations }\end{array}$ & Number of Collocations & Number of Idioms \\
\hline 00 & 01 & 00 \\
\hline
\end{tabular}

Table 05: Number of Free Combinations/ V+N Collocations/ Idioms in Copy

\section{Number 01}

With regard to Copy Number 01, there are no significant errors that ought to be mentioned, except for very few grammatical mistakes, such as the article in one case, or spelling mistakes ("responsability" instead of "responsibility"). Therefore, when such mistakes are almost non-existent, the teacher could have turned to the erroneous $\mathrm{V}+\mathrm{N}$ collocations. However, those mistakes were not taken into consideration. This, again, confirms what has been stated before, that teachers pay no attention to collocational 
errors in the essays of their students due to a lack of awareness of their importance and existence or, probably, because they had not taught them during the academic year.

It is common amongst people who are constantly exposed to English that it is not appropriate to say "to put the rules" instead of "to make/to establish the rules."

It can be said, hence, that, at least, in Copy Number 01, the teacher did not take into consideration collocations when awarding the grade.

In Copy Number 01, there were 03 cases of acceptable $\mathrm{V}+\mathrm{N}$ collocations:

1. Parents want to protect their children from negative things such as drugs. Always, they feel afraid about their future, they want it to be a better one.

2. The second cause that makes parents so strict is responsibility, it is not easy to take a good care of their children.

3. Even if they are so strict they look for something beneficial, we must respect them and follow their rules.

\section{Copy Number 02}

The mistakes that were collected in Copy number 02 can be summarised in the following points:

1. Spelling errors

2. Tense errors

On one hand, the thesis statement was well-phrased, and the ideas were, to a certain extent, adequately developed. On the other hand, from a collocational standpoint, the teacher gave no importance to the $\mathrm{V}+\mathrm{N}$ erroneous collocation in the essay.

\begin{tabular}{|c|c|c|}
\hline $\begin{array}{c}\text { Number of Free } \\
\text { Combinations }\end{array}$ & Number of Collocations & Number of Idioms \\
\hline 05 & 04 & 00 \\
\hline
\end{tabular}

Table 06: Number of Free Combinations/ V+N Collocations/ Idioms in Copy

\section{Number 02}

The following are some of the instances of the acceptable collocations in Copy Number 02

1. In this respect, families who choose to change their origin town may face many problems related to their children and their social life.

2. Rather, they are a result of a long run relationships. We build our relationships with our parents, brothers, sisters, friends and with customers in our business over a long spun of experiences and 
transactions. So, to move to a new town means to lose some of the social relationships.

\section{Copy Number 03}

The case of Copy number 03 is a confirmation that the teachers are not aware of the restricted relations between words-Verb+Noun in this case or, again, sufficed on correcting what they have taught. How come that a students' copy, which contains 08 erroneous Verb+Noun collocations be awarded 16? The answer is that, while correcting the paper, the teacher did not consider the notion of collocation as crucial in essay writing. It also shows that the teachers are not aware of the difference between "having a scholarship" and "winning a scholarship." This trend has been recurrently noted and highlighted throughout the practical side of the thesis.

\begin{tabular}{|c|c|c|}
\hline $\begin{array}{c}\text { Number of Free } \\
\text { Combinations }\end{array}$ & Number of Collocations & Number of Idioms \\
\hline 01 & 04 & 00 \\
\hline
\end{tabular}

Table 07: Number of Free Combinations/ V+N Collocations/ Idioms in Copy

\section{Number 03}

The essay contained almost no spelling or tense errors; the thesis statement was well-phrased. All these factors led the teacher to award such a good mark, neglecting the essence of many of the sentences, that is the verb and the noun that combines with it.

The acceptable collocations in Copy number 03 are stated as follows:

1. I am of course aware of the fact that every single human being is interested in a particular and certain sort of things he would like to have as a gift.

2. He is an engineer in architecture who owns his private successful company.

3. This scholarship may be a basic thing in advanced nations, but it is life saving to us, and more particularly, me. It would provide me with opportunities I have never dreamt of encountering.

\section{Copy Number 04}

The use of Verb+Noun word combinations - especially free combinations-was prevalent in Copy Number 04, the total of 17 word combinations $(09 \mathrm{~V}+\mathrm{N}$ free combinations/ $08 \mathrm{~V}+\mathrm{N}$ collocations). In addition, 07 unacceptable collocations were found in Copy Number 04. 
What is expectedly similar to the previous copies is that the teacher ignored all of the 07 unacceptable collocations, the equivalent of $46.67 \%$, and awarded the essay a mark of $14 / 15$. Even on the student's examination paper, there were no corrections concerning the unacceptable collocations.

\begin{tabular}{|c|c|c|}
\hline $\begin{array}{c}\text { Number of Free } \\
\text { Combinations }\end{array}$ & Number of Collocations & Number of Idioms \\
\hline 01 & 04 & 00 \\
\hline
\end{tabular}

Table 08: Number of Free Combinations/ V+N Collocations/ Idioms in Copy Number 04

It has to be noted that the thesis statement in Copy Number 04 was successful in terms of topic and subtopics; parallelism was achieved, in addition to appropriate punctuation. Although there were some minute blemishes in punctuation, the procedure of writing the essay in Copy Number 04 was successful, to a great extent. Nevertheless, adhering to the various essay writing techniques does not entail a total negligence of Verb+Noun collocations as major factors in determining the quality.

It is compulsory to ask this question: What is the use of successfully implementing all the writing techniques if the core of the sentences that make up the essay is unacceptable? It goes without saying that the answer is that it is useless. Another way to put it is to ask: Does the EFL student learn syntax and semantics first, or writing techniques? The answer is obviously that syntax and semantics are more important to learn, because they come before writing during the process of language learning.

Some of the acceptable collocations that were found in Copy number 04 are:

1. Every father does his best to save his child, so it is obvious that he will try anything in order to achieve his desire, and being so strict is one of the aspects that the fathers or mothers should follow and every parent has his own reasons about why he should be so strict.

2. Every father does his best to save his child, so it is obvious that he will try anything in order to achieve his desire, and being so strict is one of the aspects that the fathers or mothers should follow and every parent has his own reasons about why he should be so strict.

\section{Copy Number 05}

In Copy number 05, there were 07 Verb+Noun free combinations, 02 acceptable Verb+Noun collocations, and only 01 unacceptable Verb+Noun collocation.

There were some spelling mistakes in Copy Number 05. Other than that, the thesis statement was acceptable, with clear subtopics. It was also concise and precise. The use of tense was successful throughout the essay. Therefore, with regard to the sole $\mathrm{V}+\mathrm{N}$ collocational error in the whole essay, the awarded grade was deserved. However, the 
teacher showed, again, unawareness or neglect toward the collocational mistake that had been made.

\begin{tabular}{|c|c|c|}
\hline $\begin{array}{c}\text { Number of Free } \\
\text { Combinations }\end{array}$ & Number of Collocations & Number of Idioms \\
\hline 00 & 06 & 00 \\
\hline
\end{tabular}

Table 09: Number of Free Combinations/ V+N Collocations/ Idioms in Copy

\section{Number 05}

The two acceptable collocations in Copy Number 05 are the following:

1. In our continuous pursuit of happiness, we may travel to achieve that goal.

2. In our continuous pursuit of happiness, we may travel to achieve that goal; we may leave our homes to seek for a new life in a new town.

It needs to be noted that they were copied exactly in the same way they were written in the essays.

\section{Copy Number 06}

The number of $\mathrm{V}+\mathrm{N}$ unacceptable collocations in Copy Number 06 is 04; that is the equivalent of $40 \%$ of all the $\mathrm{V}+\mathrm{N}$ collocations. Nonetheless, the essay received 16 , a mark only given to outstanding compositions. For a composition to be labelled as "outstanding", it has to be devoid of errors, mainly syntactic and semantic. So, how come that an essay containing 04 unacceptable $\mathrm{V}+\mathrm{N}$ collocations receive such a high grade? The answer is because the teacher did not take into consideration collocational knowledge as a key component in language.

\begin{tabular}{|c|c|c|}
\hline $\begin{array}{c}\text { Number of Free } \\
\text { Combinations }\end{array}$ & Number of Collocations & Number of Idioms \\
\hline 03 & 05 & 00 \\
\hline
\end{tabular}

Table 10: Number of Free Combinations/ V+N Collocations/ Idioms in Copy

\section{Number 06}

Starting with the thesis statement, although it fulfilled the requirements of a good one, two collocational errors were spotted in that sentence. Written Expression of undergraduate second year instruct their students on how to write an appropriate thesis statement. Therefore, when correcting students' examination papers, they give more importance to the latter than other aspects of writing. In the case of Copy Number 06, the teacher did not correct the inappropriately combined verbs and nouns. This can be deduced due to the fact that they have not written any remarks, nor have they crossed or highlighted any of the inappropriate $\mathrm{V}+\mathrm{N}$ collocations. 
For the acceptable $\mathrm{V}+\mathrm{N}$ collocations in Copy Number 06, here are some of them:

1. Having an amazing car as a gift would be a great thing.

2. I would take it every night, go to the highway, and drive as fast as I can. But I would never drive it (the car) in town because I do not want someone to crash it.

To conclude this section, it is crucial to mention that the use of erroneous collocations is by no means the sole factor that contributed to the poor quality of the learners' essays. And it is also not be taken as the only variable of evaluation. Nevertheless, it is clear, thus far, that the use of erroneous collocations $-\mathrm{V}+\mathrm{N}-$ significantly lowers the quality of the written production, regardless whether the Written Expression teacher takes into account the appropriate use of collocations while correcting or not. It has to be understood that formulaic language-collocations included-makes up $80 \%$ of the language repertoire. Hence, it is undeniably to be equally taken into consideration, even if it is not taught by the Written Expression teacher, similar to grammar.

\section{Conclusion}

This paper sketched the collocational status quo of the second year EFL learners at the University of Mentouri Brothers, Constantine 1. It confirmed the first hypothesis suggesting the difficulties Algerian EFL learners have with $\mathrm{V}+\mathrm{N}$ collocations. However, the findings disprove the second hypothesis that argues for the influence of collocational errors on the awarded grades. As a whole, it is to be concluded that considering all word combinations as collocations is incorrect. It is now admitted that identifying collocations from other word combinations is difficult due to their vague nature that falls between free combinations and idioms. The study stated that in order to be able to classify a given word combination as a collocation, three criteria - or at least two - need to be met: restricted sense, restricted substitutability, and high frequency of co-occurrence. The obtained results show the indispensability of collocational competence in achieving efficiency in essay writing, therefore, language proficiency. The essays with the highest grades contained a high frequency of unacceptable $\mathrm{V}+\mathrm{N}$ collocations, a result indicating that collocational errors were not taken into consideration when awarding grades. This shows that Written Expression teachers are either unaware of the importance of collocations in determining the writing quality or did not take it into account while correcting, because they are not taught during the academic year. Therefore, the study encourages teachers and instructors to give more importance to teaching collocations as an inseparable factor to becoming a pseudonative speaker. Moreover, they are encouraged to take collocations into consideration when correcting students' essays. In addition to that, not only do learners need to be 
exposed to correct collocations, but, to erroneous ones, too. This is because the trialand-error mechanism used by L2 learners cannot be applied to ready-made chunks.

\section{References}

Bahns, J. (1993). Lexical Collocations: A Contrastive View. ELT Journal 47/1, 56-63. doi: org/10.1093/elt/47.1.56

Benson, M. (1985). Collocations and idioms. Dictionaries, Lexicography and Language

Learning. Oxford: Pergamon.

Darvishi, S. (2011). The investigation of collocational errors in university students' writing

majoring in English. Paper presented at the 2011 International Conference on Education: Research and Innovation, Singapore. IACSIT. Retrieved from: www.ipedr.com

Farrokh, P. (2012). Raising awareness of collocations in ESL/EFL classrooms. Journal Studies in Education, 2, 55-74. doi: 10.5296/jse.v2i3.1616

Firth, J. R. (1957). Papers in Linguistics. Oxford: OUP, 17, 402-413. doi.org/10.1111/j.1473-4192.2007.00164.x

Gabrielatos, C. (1994). Collocations: Pedagogical implications, and their treatment in pedagogical materials. Unpublished essay, Research Centre for English and Applied

Linguistics, 1-17. Retrieved from: www.academia.edu

Ganji, M. (2012). On the effect of gender and years of instruction of Iranian EFL learners,

collocational competence. English Language Teaching, (5), 123-133. doi: 10.5539/elt.v5n2p123

Hardi , A. (2008). A collocation-based approach to Nepali postpositions. Journal of Corpus Linguistics and Linguistic Theory, 4(1), 19-61

Hatch, E., Brown, C., 1995. Vocabulary, semantics, and language education. CUP.

Henriksen, B. (2013). Research on L2 learners' collocational competence and development - a progress report. 29-56. Retrieved from: www.eurosla.org

Lewis, M. (1997). Implementing the lexical approach. England: Language Teaching Publication, 8, 34-44. doi.org/10.1002/j.1949-3533.1999.tb00159.x ePDFPDF

McKeown, K. R., Radev, D. R. (1995). Collocations. 1-19. New York. Retrieved from: clair.si.umich.edu

Wray, A. (1999). Formulaic language in learners and native speakers. Centre for Language \& Communication Research, 32, 213-231. 
The Effect of Collocational Success on Essay Grading: A Case of Algerian EFL Learners

Wood, D. (2009). Effects of focused instruction of formulaic sequences on fluent expression.

in second language narratives: A case study.12, 39-57. Retrieved from

https://journals

.lib.unb.ca/index.php/CJAL/article/view/19898/21736 